\title{
Chapter 11 \\ The Experience with Creating University of Lorraine by Merging Four Former Universities
}

\author{
Jean-Pierre Finance, Hervé Coilland, and Pierre Mutzenhardt
}

\subsection{Introduction}

This chapter describes the setting up of the University of Lorraine, the reasons behind the merger of four "historic" universities in Lorraine, the method used to implement the merger and the lessons that can be learned from the whole process. It is composed of five parts: background (brief history of the French higher education system), the context, the merging process, the lessons learned and conclusions.

This chapter is written from a French national perspective, however, the initial strategic analysis undertaken by the universities in Lorraine and the resulting process were strongly influenced by the international and especially European academic contexts. Thus, to name but one example, the setting up of Aalto University as a result of the merger of three distinct universities with their own disciplinary fields (the Helsinki School of Economics, the University of Art and Design Helsinki and Helsinki University of Technology) reflects a similar approach.

Building up an international network with partnering universities that share a somewhat similar history as ours, that are multidisciplinary and have a strong focus on societal expectations, mixing fields that can be labelled as "hard sciences", "humanities" and "technologies", a whole set of skills we feel entitled to claim, will be one important action line in our future international strategy. A rapprochement between universities is a process that involves the whole academic world well beyond national and European borders (Walbaum et al. 2012). In this trend, we move in the same direction as the University of Copenhagen and Aarhus University in Denmark, Aalto University in Finland, the University of Manchester in the UK or The University of Western Sydney in Australia. We have already enjoyed partnerships with some of these universities and we will be able to rely upon the common experience of a successful merger to build new partnerships.

The authors thank the editors for their careful reading and constructive comments.

J.-P. Finance $(\bowtie)$

European University Association (EUA), Bruxelles, Belgium

University Henri Poincaré, Nancy, France

e-mail: jean-pierre.finance@univ-lorraine.fr

H. Coilland $•$ P. Mutzenhardt

University of Lorraine, France

e-mail: herve.coilland@univ-lorraine.fr; pierre.mutzenhardt@univ-lorraine.fr 
The first three parts factually describe the merger process. The history of France's universities is briefly reminded as well as the national and regional university context. A special focus is put on the situation in Lorraine, a region in France marked by the divergence between North and South, in and around the cities of Metz and Nancy.

The merger chronology from 1985 to 2012 puts an emphasis on the initial strategic vision and the technical, political and human difficulties to put it into action.

Part four and the final conclusion form an analysis of the merger, the methods that were used and the result achieved. This analysis made by those who have been heavily involved in the process endeavours to be insightful and realistic. Key critical points have been identified: the difficulty in sharing a long term strategic view with those who are active on the ground, the complexity of the process driven by the construction of the target institution (University of Lorraine) and the drive shared between four founding universities. However the result in an unexpectedly short time lag was satisfying. Finally it seems clear that such a process would not have been possible without the firm support of the partners (Region, National Research Bodies) of the universities in Lorraine and of the State.

\subsection{Background}

At the beginning of the twenty-first century, the French academic landscape is still influenced by decisions taken during the French Revolution in 1793. At this time, the universities, considered as corporatist and anti-revolutionary, were replaced by "faculties" (some of them being mainly focused on academic teaching disciplines humanities and sciences - the other on professional skills - medicine and law -) and "grandes écoles". The latter were strongly oriented towards professional skills, which were to have a major structuring effect on the French higher education system. This particular model lasted until 1969.

The events of May 1968 in France required a deep reform of the higher education system. The "Faure" law (named after the Minister in charge of national education at this time) re-created "universities" by merging the former faculties. This act fundamentally modernized university democracy but only partially changed the French system of higher education. Indeed, the newly created "university" often remained focused on a group of topics (which were to contribute to increasing the split between the technical sciences and the humanities). The "grandes écoles" remained mainly outside the universities, even if some of them kept their public status, and others their private status. Since 1939, a considerable part of public research activity was entrusted to Research Performing Organisations - RPOs (so-called EPST in French: Public Scientific and Technological Research Institutions): at the beginning the $\mathrm{CNRS}^{1}$ which aims to cover all

\footnotetext{
${ }^{1}$ CNRS: National Center for Scientific Research, about 11,300 full time researchers, 14,000 administrative and technical staff.
} 
disciplines, followed by various, more or less specialized institutions like INSERM, ${ }^{2}$ INRA. ${ }^{3}$ Public research was therefore carried out in universities, some "grandes écoles" and RPOs, often in laboratories whose tutorship is shared by several institutions (the "Joint Research Units").

One might therefore understand the wave of Universities mergers, started in France in 2009, as a continuation of the reorganization which had begun in 1969. But this wave of mergers is also a consequence of the on-going deep changes: the implementation of the Bologna Process, the increasing impact (even if it is denied) of international rankings and assessments, the launch of a national debate on closer links between universities and local site policies and discussions regarding the competition between the university system (wider access) and "grandes écoles" (selection process). The latter turned out to the advantage of the "grandes écoles" which became the way for preparing the elites (except for health and law).

In this context, the Lorraine experience is exemplary because it integrated "engineering schools" and abolished the French historical distinction between "faculties" and "grandes écoles" at the regional level.

\subsection{The Context}

Lorraine is the French region that was the most affected by the upheavals in European history since the end of the nineteenth century. The region's tremendous potential with its resources of coal, iron and salt made it highly attractive and the French defeat in 1870 at the hands of Germany led to Lorraine being partitioned. The effects of this division were still evident almost a century after the subsequent reunification of the region and involved the separation of the Moselle area around Metz from part of the rest of Lorraine around Nancy. This historical division has been the source of tension between the north and south of Lorraine and has also played a major role in structuring the socio-economic and cultural make-up of the region.

\subsubsection{The Chronology of the University System}

The development of the university system in Lorraine has also been affected by the rivalry between the two "capitals" and was further exacerbated by the chronology and types of universities set up in the area. Four universities were set up in Lorraine contemporaneously between 1970 and 1972, following "Faure's law" but the

\footnotetext{
${ }^{2}$ INSERM: National Institute for Health and Research in Medicine.

${ }^{3}$ INRA: National Institute for Research in Agronomy.
} 

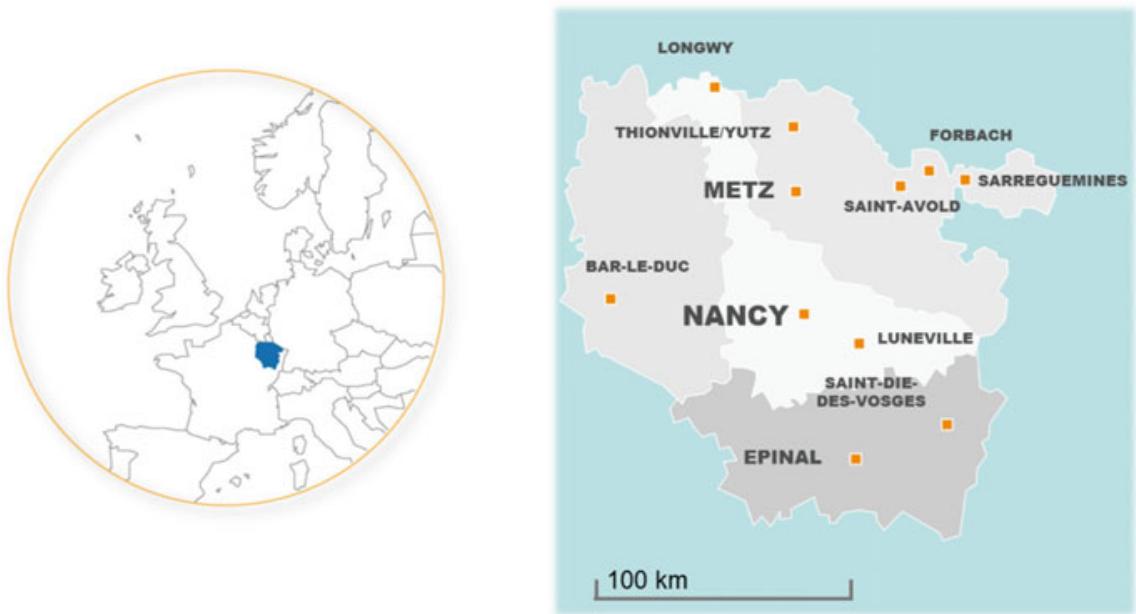

Fig. 11.1 Lorraine: geographical location and sites locations

presence of universities in Nancy dates from much earlier. University institutions were divided between complementary "Faculties" and "grandes écoles" in the middle of the nineteenth century, while Metz hosted a branch of the University of Strasbourg. When it was founded in 1972, the University of Metz took on a multidisciplinary profile (not including Faculties in the field of health) to provide the broadest range of courses possible but this multidisciplinary set-up was immediately seen as being in direct competition to the university courses already on offer in Nancy. However, over the years several joint projects have been run between Metz and Nancy (a number of Masters' programmes, the graduate schools, some joint labs especially in chemistry).

The year 2005 marked a time of much reflection and questioning for the university in Lorraine (Fig. 11.1 and Table 11.1).

This period was perhaps even more critical for Lorraine because of the economic situation in the region, which was still difficult 30 years after the steel industry crisis, the closures of the iron ore and coal mines and the end of the textile industry, all combined with demographic stagnation. Moreover, in 2005 the four Lorraine Universities began working under a new "four-year contract". It should be noted that Universities in France mostly receive public funding, which is awarded on the basis of two mechanisms. The more determining mechanism is based on a calculation of essentially quantitative criteria, primarily the number of students. The second mechanism is used to calculate funding for specific projects linked to the university's strategy.

The preparation of the 2005-2008 contract with the state at the start of 2005 was an opportunity for each university to redefine its strategy in detail. 
Table 11.1 The University setup in Lorraine in 2005

\begin{tabular}{|c|c|c|}
\hline \multirow[t]{6}{*}{ Nancy } & \multirow{6}{*}{$\begin{array}{l}\text { Henri Poincaré Nancy } 1 \\
\text { University (UHP) }\end{array}$} & Mathematics, computing, automation \\
\hline & & Materials sciences and life sciences \\
\hline & & Health, sport \\
\hline & & Engineering sciences ( 3 engineering schools) \\
\hline & & $\begin{array}{l}\text { Technology (3 University Institutes } \\
\text { of Technology, degree level) }\end{array}$ \\
\hline & & $\begin{array}{l}16,500 \text { students, } 1,200 \text { teacher-researchers } \\
\text { and teachers }\end{array}$ \\
\hline & \multirow[t]{5}{*}{ Nancy 2 University (UN2) } & Literature and humanities \\
\hline & & $\begin{array}{l}\text { Humanities, social sciences, law, economics } \\
\text { and management sciences }\end{array}$ \\
\hline & & Computing \\
\hline & & $\begin{array}{l}\text { Technology (2 University Institutes } \\
\text { of Technology, degree level) }\end{array}$ \\
\hline & & $\begin{array}{l}16,500 \text { students, } 650 \text { teacher-researchers } \\
\text { and teachers }\end{array}$ \\
\hline & \multirow{3}{*}{$\begin{array}{l}\text { National Polytechnic Institute } \\
\text { of Lorraine (INPL) }\end{array}$} & Engineering sciences \\
\hline & & (7 engineering schools) \\
\hline & & $\begin{array}{l}3,800 \text { students, } 340 \text { teacher-researchers } \\
\text { and teachers }\end{array}$ \\
\hline \multirow[t]{7}{*}{ METZ } & \multirow{7}{*}{$\begin{array}{l}\text { Paul Verlaine University - Metz } \\
\text { (UPVM) }\end{array}$} & Mathematics, computing, automation \\
\hline & & Materials sciences and life sciences \\
\hline & & Literature and humanities \\
\hline & & $\begin{array}{l}\text { Humanities, social sciences, law, economics } \\
\text { and management sciences }\end{array}$ \\
\hline & & Sport \\
\hline & & $\begin{array}{l}\text { Technology ( } 3 \text { University Institutes } \\
\text { of Technology, degree level) }\end{array}$ \\
\hline & & $\begin{array}{l}15,300 \text { students, } 730 \text { teacher-researchers } \\
\text { and teachers }\end{array}$ \\
\hline
\end{tabular}

\subsubsection{A Shared Strategic Vision for Nancy}

In February 2005 the presidents of the three institutions in Nancy decided to evaluate the overall strategic situation of the site (see SWOT analysis below) and to develop a shared strategic vision. This shared strategic vision in Nancy in itself marks the start of a profound change - moving from the sharing of support services and pooling resources to a shared political analysis. This analysis highlighted a number of strategic questions, for example the choice and priorities of scientific subjects. While the broad range of courses and research work was seen as a strong point, it was also problematic to an extent, because the broad range of courses on offer was attractive on a regional basis (at Bachelor degree level) but could also potentially penalise Masters and Doctorate level courses if these were considered insufficiently specialised. 
The possible compromise between a wide range of courses at the 1st cycle degree level and a narrower, more specialised range of Masters and Doctorate programmes could also be risky. A wide range of diversity at Bachelors level induced student dispersion into a variety of curricula. This did not always lead to the development of curricula at Masters level, yet on the other hand, it does not provide sufficient potential for local recruitment to Masters level programmes and potentially weakens the link between research and training. How could an optimal balance be achieved? While promoting excellence in certain subjects offered the means for increasing the attractiveness of universities in the region, it also meant neglecting other sectors, a socially unacceptable outcome for universities and the public at large (Table 11.2).

At the same time, universities possessed very tangible strong factors that enabled them to provide effective responses to these issues namely:

- The long history of research work in the shared laboratories (some of which were associated with national RPOs such as CNRS, INRIA, INRA or INSERM ${ }^{4}$ ) meant that the rapid implementation of a scientific policy for the site could be envisaged.

Table 11.2 Overview of the SWOT analysis

\begin{tabular}{|c|c|}
\hline Strengths & Weaknesses \\
\hline $\begin{array}{l}\text { Research laboratories shared between } \\
\text { the institutions }\end{array}$ & $\begin{array}{l}\text { Inter- and intra-institution organisational } \\
\text { and cultural heterogeneity }\end{array}$ \\
\hline $\begin{array}{l}\text { Recognised excellence in certain } \\
\text { scientific fields }\end{array}$ & Insufficient prestige, visibility and clarity \\
\hline Broad range of courses and research & $\begin{array}{l}\text { Insufficient coordination between } \\
\text { the Universities and local authorities }\end{array}$ \\
\hline Shared inter-university services & $\begin{array}{l}\text { Poorly coordinated international } \\
\text { and partnership projects }\end{array}$ \\
\hline \multicolumn{2}{|l|}{$\begin{array}{l}\text { Consultation on scientific, research } \\
\text { and course issues }\end{array}$} \\
\hline \multicolumn{2}{|l|}{ Efficient administration } \\
\hline \multicolumn{2}{|l|}{ Proactive digital policy } \\
\hline Opportunities & Threats \\
\hline $\begin{array}{l}\text { Launch of major national and European } \\
\text { scientific programmes }\end{array}$ & $\begin{array}{l}\text { Decrease in demographic and cultural aspect } \\
\text { of students who turn away from natural sciences }\end{array}$ \\
\hline $\begin{array}{l}\text { Change to staff population: planned } \\
\text { redeployment and restructuring programmes }\end{array}$ & $\begin{array}{l}\text { Ambiguity of regional policies: development } \\
\text { of flagship metropolitan projects but regional } \\
\text { dispersal }\end{array}$ \\
\hline Involving local authorities & $\begin{array}{l}\text { Increasingly competitive national } \\
\text { and international context }\end{array}$ \\
\hline $\begin{array}{l}\text { Original tools, museums, research } \\
\text { infrastructures, resources and ideas } \\
\text { to be promoted }\end{array}$ & Too much individualism \\
\hline Strong staff involvement and motivation & \\
\hline
\end{tabular}
${ }^{4}$ INRIA: National Institute for Research in Computer Science, INRA: National Institute of
Agronomic Research, INSERM: National Institute of Health and Medical Research. 
- Shared inter-university services were the basis for the construction of reinforced operational cooperation in Nancy.

- The three presidents got on well and had a frank working relationship, which meant that all issues could be discussed openly and that the future was not a taboo subject.

Although the human dimension was a determining factor, conversely it also involved the risk that the project might not be robust enough if it depended overly on the relationship between a few decision-makers. As early as spring 2005, the question arose of how to set up institutional "ratchets" or safeguards, capable of securing the emerging strategy without unduly alarming a community that might not be entirely ready for the idea of a merger of Nancy's universities.

\subsubsection{North-South Relations}

During the same period the Paul Verlaine University in Metz was also rethinking its strategy. Tensions with Nancy were progressively disappearing and the preparation of the "2005-2008 contract" had provided an opportunity to construct "jointly developed course programmes" between Metz and Nancy. The main aim of the consultation process was to avoid unnecessary competition while preserving the way courses were spread out over the region. In parallel, research coordination and cooperation was being consolidated between Metz and Nancy. However, the Paul Verlaine University was also working on its own development within the home territory (the Moselle area) having benefited, since its setting up, from the solid support of the local authorities and the socio-economic landscape of the dynamic Moselle area. In 2006, the setting up of ISEETECH (the Higher European Institute for Business and Technologies), a coordinating body for the Moselle area, clearly demonstrated this dual political and economic involvement in higher education. The Paul Verlaine University was to play a major role in this Institute.

The Universities of Metz and Nancy were each equally unsure as to whether their neighbour was more of a threat or a potential partner. The idea of the universities coming together first came up in Nancy because of their geographical proximity, being located on the same site, and the complementary nature of the disciplines taught. However, the idea of a federation was still a long way from being accepted in Nancy, let alone a merger. Two main types of higher education programmes existed side by side in Nancy, namely, more classical academic courses and engineering courses that tended to be interdisciplinary. There were also significant organisational differences and divergences regarding teaching methods and professional perspectives for students. The main organisational difference lay in the entrance processes to courses, as mentioned earlier. To add to the complexity, in Nancy, seven schools were grouped together in one single institution with its own particular status (the INPL) and three other schools made up a more "conventional" University (UHP). Therefore at the start of 2005 there was 
only talk of bringing Nancy's higher education institutions "closer together". When this began to occur, it appeared that the North-south divide between Lorraine's universities might develop even further and lead to a definitive divide in higher education in the region in the future. The following period was thus to prove critical.

\subsection{The Merger Process}

\subsubsection{Phase 1: Strategy and Pragmatism (2005-2007)}

The merger process leading to the setting of the University of Lorraine evolved over five phases. The first phase was to leave its mark on the whole process, providing a method for simultaneously working on the strategic planning, the progressive pooling of resources and services, and the operational management of the joint projects being set up. The relations between Metz and Nancy were developing but closer and more tangible links were being forged between institutions in Nancy leading to:

- The setting up of the "Nancy-University Federation" which took the idea of the "Nancy-Universities" label created in 2001 much further.

- Regular meetings of the three presidents (G3) and of a "political think tank" (G9).

- The setting up of the "Scientific Coordination and Steering Committee for Lorraine (CCOSL)" at the start of 2007, bringing together the four Universities, the four national research institutions in Lorraine and the Nancy University Hospital Centre (CHU).

- The setting up in March 2007 of the Nancy-University PRES ${ }^{5}$ providing institutional support for the Nancy Federation.

\subsubsection{Phase 2: The Turning Point in Lorraine (2008-2009)}

2008 was to be a crucial year for the future of universities in Lorraine. The four Lorraine Universities decided to make a joint bid for the "Campus" call for projects launched by the French government at the start of the year. This decision and its consequences were to trigger the process that led to the merger. Following the joint project's initial failure to be selected in July 2008, the local authorities, including those in the north of Lorraine, agreed to support the property development

\footnotetext{
${ }^{5}$ PRES: The Lorraine Research and Higher Education Pole (in French: Pôle de Recherche et d'Enseignement Supérieur) was set up with the status of a French Public Institution for Scientific Cooperation (EPCS) as set out in a law from 2006. Decree $n^{\circ}$ 2007-384 dated March 21st 2007 (Légifrance 2011).
} 
programme (which was mainly a sub-project of the initial one) focused exclusively on Nancy and to remain partners in this new plan "from the Lorraine region". In July 2008 the cities of Metz and Nancy and the Moselle (North) and Meurthe and Moselle (South) areas and the Lorraine Region all signed a "territorial pact for the University of Lorraine" (Eureka 2011; Région Lorraine 2011). The concept had not been clearly defined in its entirety at the time but this support for the LorraineNancy "Campus" project confirmed that the whole region was involved in the process of bringing higher education institutions closer together.

The "Lorraine Campus" project was finally approved by the French government in December 2008 but in September 2008 the three Nancy Universities and the University of Metz had already voted to "mandate their president to lead work in bringing institutions closer together", work to be carried out by all four! Thus in October the G3 became the G4 (bringing together all four presidents) and met weekly until December 2011 thus truly co-steering the four Universities in Lorraine. On May 12th 2009 at a joint meeting, the four Boards of Governors approved the development of a "project scheme" and more specifically the setting up of political working groups (made up primarily of members of the councils) to manage the organisation and governance, research, training and human resources. In October 2009 the Nancy-University PRES became the "PRES of the University of Lorraine" with a new threefold mission, to manage joint projects, provide logistical support for the upcoming merger and to provide a framework and assistance for the four universities strategic planning.

During 2008-2009 the Boards of Governors expressed their support for this process clearly, though cautiously. In September 2008 they "authorised planning" for bringing the universities closer together while in May 2009 they gave their views on the work being done. However at this stage, no tangible developments were achieved and the statutes and organisation of the future "UL" remained to be defined. Only when this was completed would the governing bodies be able to decide whether to confirm the merger.

\subsubsection{Phase 3: The Period of Major Joint Scientific Projects (2010-2012)}

The "Projet Investissements d'Avenir" (PIA, Investment for the Future Project), was launched in France at the start of 2010. The four Lorraine Universities jointly replied to the various calls for projects with varying degrees of success. It was particularly disappointing in February 2012 when the University of Lorraine (in existence by then) did not manage to secure approval for the project it developed in response to the "Excellence Initiative" call, despite reaching the final selection phase. The joint response from the four Universities to all the calls for projects enabled them to work together on scientific planning which had previously never been the case at that level. This helped to define the structuring of scientific directions for the future. The PIAs were an opportunity that helped accelerate the merger process. 


\subsubsection{Phase 4: The Construction of the University of Lorraine (2010-2012)}

The schedule for the planned merger was dependent on internal electoral timelines. Only one date was possible for the start-up of the University of Lorraine: the beginning of 2012, as it was difficult to find a suitable date before 2016 due to the election of the Boards of Governors and Presidents for a 4-year period. At the start of 2010 designing the structure of the future organisation became a priority. A key issue to be addressed related to whether teacher-researchers were to form part of the "teaching units" 6 and research laboratories. This was not clearly defined and varied according to their area of scientific work. It was therefore impossible to set up a mono-dimensional structure in many sectors and therefore a matrix form of organisation was selected. There were 85 laboratories and 45 teaching units within the four Universities. It was not possible to carry out an in-depth restructuring of these labs and units in the short term particularly because this would require the merger of units belonging to different institutions. An intermediate organisational level was needed: collegiums (which would bring together the teaching units) and scientific poles (bringing together the laboratories).

In June 2010 the Boards of Governors worked on and approved a political statement of the three main ambitions they had set for the University of Lorraine:

- To meet the double challenge of excellence and proximity.

- To build a "Campus for the Region" with our partners.

- To take control of our future.

In July, work began with the French authorities to formulate the statutes for the future UL. The status of "Grand Établissement" (Major Research and Higher Education Institution), ${ }^{7}$ which would be a derogation in relation to the "Law Relative to the Freedoms and Responsibilities of Universities" (LRU or Law Pécresse) was designed to adapt the governance and organisation of the future institution to its broader geographical territory and to the diversity of its constituents. In January 2011, the Boards of Governors approved the planned statutes and the merger itself despite the opposition of certain student organisations and part of the university community. Operational working groups, led by internal sector experts to prepare the actual merger of services in practical terms, then replaced the political working groups.

In May the French National Higher Education and Research Council (CNESER) gave an unfavourable opinion on the draft decree setting up the UL. As this was an

\footnotetext{
${ }^{6}$ Teaching unit could be a faculty, an engineering school or a university technological institute which is, in France, a dedicate model of technological teaching unit delivering diploma below Licence.

${ }^{7}$ A special legal status for academic institutions which allows flexibility of internal organization but has been little used for conventional universities.
} 
advisory position, the government continued with the process, submitting the decree project to the French Conseil d'Etat (Council of State) whose approval was compulsory given the UL's requirement for derogation.

\subsubsection{Phase 5: Creation of University Authorities: December 2011 to June 2012}

On September 22nd 2011 the University of Lorraine was created by decree (Légifrance 2011) and a transitional phase began with an Interim Board of Governors, whose main role was to prepare for the elections of the future UL's authorities. A student organisation immediately appealed against the decree but this was rejected by the Conseil d'Etat.

In December 2011 the collegiums and scientific poles elected their boards and directors. The elections for the "central councils" took place in February 2012. Due to successive appeals, the election of the President by the Board of Governors and the setup of the leadership team were delayed until May 25th 2012. Although without political impact, these appeals greatly delayed the implementation of the presidential team, which therefore could not address the most pressing issues before September.

\subsection{Lessons to Be Learned}

There are a number of lessons and success factors which can be derived from the Lorraine University merger experience, including:

\subsubsection{Decisive Initial Commitment and the Originality of the Approach}

Two key points stand out from the above summary - the origins of the merger process and the methods used to bring it to fruition.

\subsubsection{An Approach Based on a Shared Analysis and Mutual Trust}

The merger project was born of the determination of the university presidents and their teams who shared the same analysis and vision of the future when they met in Nancy in 2005. Their determination was only possible because of their good 
relations and mutual trust. This was confirmed in 2008 by the personal commitment to the project shown by the President of Paul Verlaine University Metz at a time when the "Campus Plan" could have caused the university world in Lorraine to explode. The project and approach were initially based on the mutual trust of a small group of people and benefited from the unfailing commitment of the idea's initiators despite points of uncertainty and opposition to the merger. It did however suffer from the following two weak points:

The project would have been jeopardized if any of the main initial participants had lessened their commitment or if an external event had led to a change in the decision-makers involved. (This did in fact occur during the elections in 2006 and 2011 of new presidents at the INPL and UN2 but the new incumbents shared the same commitment as their predecessors). The university community did not become sufficiently engaged in the project and often tended to think that the project was "the presidents' business" which led people to becoming uninterested in and even opposed to the merger.

\subsubsection{A Method Combining in Parallel the Political Aspects of the Project, Operational Management and the Preparation of the Target Operational Organization}

Close examination of the dates of events shows that the real decision to merge was taken in January 2011 when the four Boards of Governors approved the draft decree. Therein lies the originality of the method used. Rather than starting from a founding political goal and then rolling out the project, almost the opposite occurred. From 2008 to 2012 the four universities were steered completely by the G4 whose weekly meeting conferred a unique character to the merger project in Lorraine. The increased level of cooperation from 2010 onwards even led those who were in favour of the idea of a University of Lorraine to conclude that the Lorraine federation already existed and was functioning properly, and thus proceeding further with the merger was unnecessary. Whereas in effect the way the structure functioned was both complex and fragile because it was not founded on established statutes.

Closely linking the running of joint projects on an operational basis to the strategic planning for implementing the merger did tend to increase the complexity of the overall project, a criticism often expressed at this time. Conversely, a method which proved particularly effective in the Lorraine context, was the decision to work simultaneously on the merger strategy and on increasing operational links. It meant progress could be made very quickly, despite the complexity of the initial situation, by progressively helping the teams involved to get to know each other and by facilitating the joint construction of projects. The strong individual commitment of the originators of the merger guaranteed a stable and clear line of strategic 
direction which gained the trust and support of those involved outside the University even if internal support was less easily obtained. But was internal support possible during a period when French universities were undergoing a phase of profound change?

\subsubsection{Perception Among the Academic Community (November 2008-February 2009)}

Beyond the positions held by groups with specific political and trade union commitments, a survey was undertaken among 75 stakeholders (research unit directors, student and staff representatives) between November 2008 and February 2009. Respondents were asked to express their expectations and reservations regarding a unified University of Lorraine whose form was yet to be defined at the time. Even though this survey did not lend itself to statistical analysis, the answers were interesting in qualitative terms.

In response to the question "Why create one single university in Lorraine?" there were four main types of answers:

To exist in the future which seemed easier if united rather than separate. Such responses involved several key notions like visibility, academic reach, readability, impact, safety, survival, credit and necessity;

- To serve the community by creating a new opportunity, higher profile and solutions for certain societal demands. The "Campus Region" concept (meaning campus throughout the region, in contrast to the concept of "city campus" or "campus area") was associated with territorial distribution and a regional identification of territorial scopes in connection with those of the (future?) University;

- To change by facilitating internal, physical and subject-related mobility, smooth circulation of ideas, cross-disciplinarity, complementarity and training linkages and bridges for students;

- To be ambitious by leveraging a boost in potential as a result of bringing universities together and extending capacities to take risks and innovate, etc.

In response to the question "How to build a single university in Lorraine?", respondents almost unanimously approved of the proposal to bring universities closer together, provided benefits could be gained from increasing levels of scientific excellence without sacrificing the regional distribution of locally available educational programmes (Bachelor level). But opinions differed as to the ways and means of implementing such a merger: was it to involve federated institutions, which would remain independent, or was it to become a full merger? The merger model was perceived as a source of concern because of the expected organisational burden and the risks of imposed job shifts in the Region.

It is important to note that issues that had emerged in 2005 at a time when a strategic analysis process was initiated in Nancy, found their echo among a section 
of the academic community in Lorraine in 2008. The respondents' answers reveal that the merger was expected to combine the diversity of the subject spectrum while promoting and improving its "shining rays", a balance that was seen as impossible to achieve in each university separately. These were the observations that inspired the objectives set out in the policy documents submitted to the Board of Governors in 2010 .

\subsubsection{External Incentives and Opportunities}

The role of external factors in the merger process is significant with certain external factors being perceived as a threat in 2005. These included demographic pressure and national and international competition, which contributed to encouraging initial strategic analysis. Legal and organisational evolutions in the environment of French universities (Acts concerning research, the PRE and autonomy and responsibilities of universities) required each institution to adapt and provided opportunities for common initiatives. Maturity dates in regular contracts with the State in 2006 and 2010 were the same for the four Lorraine universities and this led to a common timing in the planning process and the necessity of conducting a strategic analysis seemed more efficient if conducted jointly. Finally, although not a determining factor, emulation of other universities also came into play. There was particular curiosity about what had brought about the creation of the University of Strasbourg, for example, even though the situation in Strasbourg differed from Lorraine in that it was restricted to one single metropolitan area.

Two opportunities that could not have been foreseen in 2005 significantly boosted the merger process (without being decisive factors) and helped the merger to actually occur before the initially planned date of 2016. The Campus initiative, followed by the PIAs, brought the institutions closer together. The former initiative, as already mentioned, acted as a boost, while the PIAs were opportunities with an accelerating effect rather than actual objectives.

Did the Lorraine universities react to threats, seize opportunities or deliberately chose to launch the merger initiative to join forces? Undoubtedly all three played a role though the very proactive initial approach was fundamentally decisive. Above all, the oft cited reason that "there was no choice", is not considered valid. Even taking into account potential threats and opportunities, the four institutions could still have remained separate while improving their partnerships without sharing a single common strategic approach. Long-term outcomes might well have been very different.

\subsubsection{Necessary and Crucial Support}

As opposed to what could have been sources of external pressure, numerous examples of support that backed up this initiative were essential prerequisites for its success. 
First and foremost, supportive local authorities of all political persuasions and at all levels of authority (City councils, Departments and Region) proved instrumental. This support was asserted concretely twice when territorial pacts were published and put an end to a long period of tensions and uncertainties. The local authorities did not impose the merger but backed academic stakeholders so long as their initiatives involved all the universities in Lorraine.

Secondly, scientific support played a key role. As early as January 2007, the national research organisations supported the concept of a regional scientific policy. They fully committed themselves to helping the universities build their scientific programmes during the future investment programmes (or PIAs). They had naturally come to the conclusion that they would now have "one" university counterpart in Lorraine. They did not interfere in the merger process, as they were satisfied that this de facto unity had turned de jure.

Last but not least, State support was the third key enabler. The State showed interest in the Lorraine initiative as early as 2005 before the changes that occurred over subsequent years because it saw the project as a demonstrator from two angles. First, it would provide a single university for one geographical administrative region, and secondly it brought together universities (as they are usually understood in a French perspective) and "Grandes Ecoles" which had been historically separate in France until then. This support became particularly apparent in the final stage when it became evident that a special status for the new University would be necessary.

\subsubsection{The Human Factor as a Critical Point}

While the wealth of institutions lies in their human resources, it is that very human factor that was the most difficult to take into account in implementing the merger in practical terms. Without actually going as far as calling it a "culture shock", habits and attitudes were quite different in each institution owing to their historical roots and their disciplinary fields. Even though governed by law, the practices of "academic democracy" differed substantially and led to long debates in the task force that was to address organisational and governance issues. These debates were all the more sensitive because the special status planned for LU in 2010 left more room for manoeuvre as to the construction of representative bodies. Thus, dialogue conditions with staff and student representative organisations took several forms, ranging from the conflictual to the constructive, according to the labour organisations. The transition from four original institutions to one single university brought about an increase from 360 elected representatives to 537 - at equivalent staffing and enrolment levels - which indicates that "academic democracy" was not affected by the merger.

In addition to institutional differences, practices and attitudes, varied with regard to partnerships with local players (business and society) in the vicinity of the university. At the risk of an oversimplified analysis, it is understandable that the 
engineering school maintains a level of links with industries, which is different from the department of literary studies. However, this aspect was one of the merger's challenges: to share perspectives and practices while ensuring respect for the different identities and cultures of each sector.

In June 2010, the prospect of designing a new organisation raised concerns among staff with regard to possible changes in location that it might bring about. A Charter was signed by the four university presidents stating that the merger would not impose a relocation of workplace to another city. However, it contained no undertaking to ensure a convergence of optimal social conditions. There were numerous disparities between institutions in terms of human resources management, allowance systems (premiums), and especially the organisation of work time. Aligning all these items with the most favourable scheme was unsustainable for the budget of the new university. This was by far the most critical issue. In November 2012, the Board of Governors managed to pass a vote on this matter. Even though some non-majority labour organisations endorsed this agreement, the resulting overall social discontent is still far from being appeased but no other solution was reasonably conceivable.

During the whole process, two reactions, both of which are usual in such circumstances, could be observed:

- Opposition between the proponents of a project-oriented mind-set and those allegedly caught in a structure-based framework. Both groups seemingly forgot that these approaches could be complementary and mixed together.

- Criticism of a lack of communication despite the existence of a dedicated website, the distribution of printed and digital material and some 40 mailings directly sent to the universities' employees in 2 years.

However, in communication and pedagogy the receiver is never wrong; the problem lies with the sender. No doubt, this is where the approach could have been improved. It would have been more effective if "academic middle management" had been mobilised as local relays. However, in universities, middle managers are also elected representatives who may be very reluctant to convey a message perceived as coming from the higher strata. But in 2011, most heads of administrative and technical departments had been involved and played a decisive part in preparing the organisational merger process. It is questionable whether they should have been involved at an earlier stage.

\subsubsection{Choosing a Status}

In France, universities are public institutions of a scientific, cultural and technical nature (so-called Etablissements Publics à Caractère Scientifique, Culturel et Professionnel - EPSCPs) whose legal framework is set out by the Education Code (Code de 1'Education). Pursuant to its Article L717-1, institutions can be created as Larger Higher Education establishments that may depart from the 
common rules of the organisation and governance of universities. In 2012, there were only four French institutions with this status: the Grenoble Institute of Technology (Institut Polytechnique de Grenoble), The Bordeaux Institute of Technology (Institut Polytechnique de Bordeaux), University Paris-Dauphine, and Lorraine University (Université de Lorraine - UL) which is the only large-scale fully cross-disciplinary institution with this status.

Integrating seven engineering schools into UL was the main reason to choose this status. As they were already pooled together in the INPL, they needed guarantees for maintaining their identities and the way they are organised. Opting for a special status meant the existence of an "Engineering Schools Collegium" could be included in the decree setting up UL. This is the only collegium to be explicitly mentioned in the decree and it comprises the seven schools that belonged to INPL and three others from the former Henri Poincaré University. This is a very firm guarantee that UL is hereby not entitled to abolish or fundamentally change the collegium by a mere decision of its governing bodies. A special status was necessary to ensure such a guarantee; otherwise the decree could not have contained provisions on the internal organisation of UL.

This status was a necessary prior pre-condition for the engineering schools (grandes écoles) to endorse the project and it also helped to define internal and governing bodies which are adapted to the size of UL. However, it also caused two difficulties:

- The greater freedom it afforded, complicated the preparation of the status on a political level; with each category (faculty, technical and administrative staff, students) wanting to take advantage of this freedom to set up a balance within the governing bodies as stipulated by law.

- The creation of the institution required a more complex legal process, which needed to be endorsed by the French State Council (Conseil d'Etat).

\subsubsection{Current and Future Challenges}

The academic community in Lorraine initially expressed radical opposition to the merger, including understandable concerns, high expectations and a strong desire to be involved in the process. Following the merger, the reactions included a mix of regret, a wish to go forward, doubts and satisfaction.

The first kind of opposition was ideological. For those who questioned the validity of the universities' autonomy, and disputed the concept of "excellence" or for those who were unwilling to go along with the notion of competition, there were no grounds for approving a process that partly relies on the necessity to adjust to such a background. Once implemented, the merger did not change these reasons for opposition that instead turned into regrets and attempts to contradict the political decisions now made within UL. But this is part of the normal democratic 
functioning in universities. Numerous other concerns were expressed concerning the risk of setting up a new institution whose size and diversity was felt to make its governance difficult and its organisation more complicated. Members of the engineering schools from the former INPL, in particular, were used to a smaller-scale institution with short and reactive decision-making processes. The subsidiarity principle was adopted in the UL statutes to address this concern, together with the engineering school collegium, which is the only one to be explicitly mentioned. This has remained a concern since September 2012 when the university officially started to operate, but it is an issue that is being carefully monitored by the governing team.

However, the merger has already proven beneficial for the scientific policy because it has already paved the way for an agreement with research organisations in which a subject-based policy is clearly formulated. The merger is also expected to promote cross-disciplinary endeavours even if more significant research and educational projects have still to come to fruition.

A community that has been through such a mutation is naturally inclined to express more regrets (or indifference) than satisfaction. Even for those who express their satisfaction, the most sensitive question still remains definitively unanswered, namely - was this type of merger worth the advantages gained? All the arguments put forward to justify this choice on the grounds that other options could not function will never be fully convincing and acting experimentally in this field would have been particularly difficult! There are concerns that the policy-making team is too distant from the grass-root level, and there are worries about administrative complexity, loss of identity and fears of extensive restructuring of education programmes. But UL has been operational for less than a year at the time of writing and most of this discontent can be eased by appropriate internal decisions.

It must be noted, however, that most difficulties encountered at present are caused by the current economic situation and external circumstances. Owing to the economic crisis, there is not much room for manoeuvre to rapidly launch large-scale research and educational efforts that would have contributed to giving a more beneficial impetus. However, the UL is now in a much more favourable position when entering into negotiations with national authorities than was the case with the four separate institutions. In itself, this status opens up prospects that need to be shared internally and which should bear results in the upcoming contract period (2013-2017).

The text presented during the Governing Board session of 2010 propounded seven principles for the organisation: Diversity, Proximity, Territoriality, Dependability, Subsidiarity, Reactivity, and Collective Responsibility. The university bylaws are fully consistent with all these principles. The implementation of certain principles, in particular diversity, dependability, subsidiarity, territoriality and collective responsibility are both satisfactory and discernable. Reactivity and proximity are still a cause for discontent but their impact can be improved in the short term. Regular review of the project's stated goals is most important because their achievement is the major indicator of success of the merger. 


\subsection{Conclusions}

Can we extract first lessons from the merger? A strong strategic commitment shared by the Presidents and their close collaborators since 2005 , as well as the strong support of political and scientific partners were crucial in carrying out the merger in 2012. Even the most optimistic could not imagine this happening before 2020 , and pessimists did not see it happening at all! Was the method of combining strategic projects and operational management the most effective one? The definitive answer is impossible to give, but pragmatically, one can conclude that this was a successful method. The critical success factor is to involve teams in the process and to keep the community informed on an ongoing basis of the progress on the merger. There is always room for improvement. Finally, certain opportunities which were undertaken with greater or less success ("Plan Campus", "Investments for the Future"), played a role as accelerators without having proven to be necessary or sufficient for the completion of the process.

By comparing the situation in 2012 to that in 2005, it is clear the merger process has brought about greater recognition for Lorraine University both nationally and internationally. Such recognition has been reflected in the reputation earned during the "Campus" and PIA efforts and the ability of UL to devise a credible scientific strategy with its partners (which is hardly achievable for separate institutions with national-level research organisations). UL's ARWU 2013 (ARWU 2013) - or Shanghai - ranking improved immediately, due to effect of size, (rank between 201 and 300) but time is needed to assess the impact of the new identity on national, international, industrial and academic partnerships. UL is now one single direct contact for its partners, thus strengthening confidence in its long-term position and stable alliances. Another positive factor in this respect is the appointment of a Vice-President for International Affairs and Partnerships, with power to call upon departments specialised in the field to quickly consolidate existing initiatives and start new ones consistent with a genuinely institutional policy.

As far as proximity is concerned, UL will preserve and maintain curricula, at least for degree levels, based on a territorial distribution of training programmes and users' service provision. Creating a first year of Health Studies in Metz has even strengthened its profile. Owing to the current situation, the four former institutions would have been hard put to preserve their curricula on site. Finally, UL has the capacity to develop the university life aspects of its policies, which the former universities would only have been able to do through complex systems of contractual arrangements. Overall, by overcoming the need for these institutions to enter into agreements between one another, greater simplification is expected to be achieved in all fields in the long run, even if this is not yet apparent.

Aggregating excellence and proximity has now become part of the daily reality for UL. UL has achieved regional political and socio-economic status, and its attractiveness will contribute to that of Lorraine. The superposition of academic and regional perimeters enables consistent training, research and innovation policy-making. Partnerships with the local economic network, especially SMEs, are still considered insufficient but UL can provide both a single entry point 
to further contacts and a large spectrum of action spheres to facilitate projects. When economic and political initiatives are set up outside the region, at crossborder, national or international level, it is easier and more efficient to build up fact-finding task forces comprising academics, business and policy-makers with one university rather than four. A pool of regional academic stakeholders has begun to emerge with UL as an aggregator. In this way the Campus Region, a single university, distributed throughout the region, has become a reality. Its membership in UniGR (Greater Region University) extends the notion of Region to a larger cross-border dimension, which, hopefully, is in line with the future of Europe.

The prospects for the future forced the former universities in Lorraine to find ways to be able to defend themselves against possible threats and it may now be reasonably assumed that they are stronger as a single university. However, the future also calls for the development of new capacities of initiative, innovation and development. The potential is there for the political leadership to harness these capacities, but only time will tell if the new UL will be successful in steering its future.

Open Access This chapter is distributed under the terms of the Creative Commons Attribution Noncommercial License, which permits any noncommercial use, distribution, and reproduction in any medium, provided the original author(s) and source are credited.

\section{Appendix: UL Structure, Organisation and Key Figures}

\begin{tabular}{|c|c|}
\hline 53,000 students & 830,000 sq. $\mathrm{m}$ premises \\
\hline (inc. 7,800 foreign students) & (app. 8,934,045 sq. ft) \\
\hline Faculty: 3,800 & 517 ha estate (app. 1,280 ac) \\
\hline Staff: 3,000 & $555 \mathrm{M} € /$ year consolidated budget \\
\hline Scientific poles & Collegiums \\
\hline $\begin{array}{l}\text { Agronomy, agriculture and food industry, } \\
\text { forestry }\end{array}$ & Arts, literature, language studies \\
\hline Biology, medicine, health & Law, economics, management \\
\hline $\begin{array}{l}\text { Knowledge, linguistics, communication, } \\
\text { societies }\end{array}$ & $\begin{array}{l}\text { Education of teachers, institute for life long } \\
\text { learning, Institute for German Studies }\end{array}$ \\
\hline Chemistry and molecular physics & Engineering schools and preparatory schools \\
\hline $\begin{array}{l}\text { Energy, mechanics, process and product } \\
\text { engineering }\end{array}$ & Medicine, pharmacology, odontology, sports \\
\hline $\begin{array}{l}\text { Informatics, automation, electronics and } \\
\text { mathematics }\end{array}$ & Life and physical sciences \\
\hline Materials, metallurgy, mechanics & Humanities and social sciences \\
\hline Lorraine earth and environment observatory & University Technological Institutes \\
\hline \multicolumn{2}{|l|}{$\begin{array}{l}\text { Law, political science, economics and } \\
\text { management }\end{array}$} \\
\hline Time, space, literature and language studies & \\
\hline
\end{tabular}


11 The Experience with Creating University of Lorraine by Merging Four Former. . .

\section{References}

ARWU. (2013). Academic ranking of world universities. [Online] Available at: www. shangairanking.com

Eureka. (2011). Ce qui va changer avec l'Université de Lorraine. [Online] Available at: www.eureka.lorraine.eu

Légifrance. (2011). Décret n 2011-1169 du 22 septembre 2011 portant création de l'université de Lorraine NOR: ESRS1113874D. [Online] Available at: www.legifrance.gouv.fr

Région Lorraine. (2011). Un pacte territorial pour l'enseignement supérieur, la recherche, l'innovation et le développement des entreprises en Lorraine. [Online] Available at: www.net-education.cr-lorraine.fr

Walbaum, B., Loisel, S., Scheftel, H., \& Gjosteen, F. (2012). Quels enseignements tirer des regroupements universitaires? Paris: Dual Conseil \& Kurt Salmon. 